\title{
Sport Participation Motives in Primary School Students 小學生參與運動的動機
}

\author{
Ann Po-chun WONG Silu-yin CHEUNG \\ Department of Physical Education, \\ Hong Kong Baptist University, HONG KONG
}

黄寶珍䍡小燕
香港浸會大學體育學系

\begin{abstract}
The purpose of this study was to investigate the sport participation motives for primary students in Hong Kong. The subjects of this study were 9 to 13 years old Primary 4 to 6 students, with 89 males and 216 females ( $N=305)$. The Participation Motivation Questionnaire (Gill, Gross \& Huddleston, 1983) was utilized to examine the sport participation motives (Achievement/ Status, Team, Fitness, Energy release, Skill, Friends, Fun and Miscellaneous) and the sport participation pattern. 2 × 2 × 2 ANOVA was utilized to find out the mean differences on motivational factors for males and females with different age group in different type of schools (whole day and half day). Results showed that males had significantly higher mean score on miscellaneous factor than females, the younger age group had significantly higher mean scores on fun and friends factors than the older age group; and the whole-day primary school students had higher mean scores on team, friends and miscellaneous factors than the half-day primary school students. No interaction effect was found on age group and school type on motivational factor. Independent T-test was utilized to examine the mean difference on motivation factors for sport participants and non-sport participants. Results showed that sport-participants had significantly higher mean scores on team, fitness, energy release, friends and fun factors than non-sport participants.

摘 要

本研究目的為探討小學生參與運動的動機及其參與運動的形式。研究對象為9至13歲之小四至小六學生, 共有89位男學生及216 位女學生參與(總數=305)。是次研究主要透過問卷調查小學於參與運動中所能獲得之成就動機(成就感、團體精神、強健的體魄、宣洩 精力、技術、朋友、快樂及其他因素等八方面)。研究結果顯示隨著年䶖的增長, 小學生參與運動的情沉明顯地減少。男女生在其他因 數方面亦有明顯的差別; 就讀全日制的小學生在團體精神, 朋友及其他因數等方面較就讀半日制的小學生為高。而年輕的學生於團體 精神朋友及其他運動動機較年長的學生為高。本研究並無發現年齡與學校授課時間的長短於參與運動的動機有著交互影響。在空閒時 間參與運動的小學生於技術、體塊、宣洩精力、朋友及快樂等運動動機方面較沒有參與運動的學生有著較高的分數。
\end{abstract}

\section{Introduction}

Nowadays, people are more concerned with children's behavior in sports and the growing popularity of sport for children has lead to a larger amount of research into children's participation motivation. This research paper aims to review the major motives and the sport participation pattern of children in sports.

\section{Motivation in Sports}

There were numerous investigations about the motivation for children participating in sports. Motivation theories would be useful in helping to structure programs and help teachers to set strategies that are more likely to keep children interested in staying active in sports. 
Motivation is one of the most basic concepts that has been thoroughly studied in psychology, it is mainly due to two facts: (1) motives cannot be observed, and (2) there is no single motivational mechanism or theory that can explain all human motivation (Iso-Ahola, 1989).

Motivation is an internal factor that arouses and directs human behavior. Research findings stated that there were a variety of reasons for participating in sports included (a) fun (wanting to have fun), (b) fitness (being physically active), (c) competence (learning and using sport skills), (d) making positive use of leisure, (e) affiliation (reacting to peer pressures and maintaining social contacts) (Vogler \& Schwartz, 1993, Weiss \& Petlichkoff, 1989). Weiss and Petlichkoff (1989) pointed out that there was variation in the motives cited, but children have multiple motives for sport involvement and they focused primarily on reasons such as improving skills, being with friends, fun, becoming physically fit, liking the challenges, and experiencing success. Taylor, Blair, Cummings, Wun, and Malina (1998) investigated the participation motives in sports of the preteen and teen, and found that to have fun, to improve skills and to learn new skills, to be with friends or to make new friends, for thrills and excitement, and to become physically fit were the top motives. Research on motivation for involvement in youth sports clearly supported that ìfunî was a major reason for the participation of young athlete (Scanlan \& Lewthwaite, 1986).

\section{Age and Motivation}

Individuals have multiple motives for sport participation and these changes with age. A study has found that children started to participate in sports at the age of 7 to 8 or even younger but the number of dropout was increasing with increasing age (Knop, Engström \& Skirstad, 1996).

Biddle (1992) discovered that challenge, skill and competition were participation motives associated with the younger age groups, while competition appears to decline rapidly as a major motive during adolescence. Study which was conducted by the Michigan Youth Sport Institute in the 1970s found that the number of children involved in the traditional sports, such as baseball, softball, swimming and basketball increased dramatically from ages 5 to 12 years, but declined significantly at ages 11 to 13 years (Weiss \& Petlichkoff, 1989).

\section{Gender Differences in Motivation}

Gender refers to social and psychological characteristics and behaviors associated with females and males (Gill, 1994). Eccles and Harold (1991) demonstrated that gender role influences children's sport achievement perceptions and behaviors at a very young age, and that gender differences seem to be a product of gender role socialization. Historically, females have been neither encouraged nor expected to engage in physical activities. Gender differences in athletics were assumed to be physiological in nature and males believed to be stronger, faster, and naturally better athletes than females (Estrada, Gelfand, \& Hartmann, 1988). The study of Gould et al. (1985) stated that young female swimmers (age 8-19) placed greater emphasis on fun and friendship than male swimmers. In addition, Kirkby, Kolt and Liu (1999) showed that male gymnasts reported reasons related to the Excitement factor as more important to their participation than female gymnasts.

\section{Benefits of Sport Participation}

Through sports, children may learn how to deal with the dilemmas of adult life, without having to suffer harsh consequence in the 'real world' (Grove et. al., 1994). Youth sport could help to develop character, spending time with a team was an intense emotional experience, rich in social interaction, abundant in moral challenges, replete with opportunity for the exercise of moral virtue. Therefore, it might help to develop the following characters: Compassion, Fairness, Sportspersonship and Integrity (Shields \& Bredemeier, 1995).

Coakley (1993) found that children might be benefit from participation by gaining an increased sense of physical selfmastery, increased abilities to deal with authority and peers, and increased opportunities to develop friendship crucial to social development. Participating in sport also could have positive effects on children's emotion control. Jung (1998) found that the anxiety level could be decreased through participation in physical activities. Thus, most people participated in sport in order to maintain a healthy psychological situation.

Sport participation is important for children, with benefits not only for their physiological state but also their psychological state. Children living in Hong Kong need to face high pressure, these pressures come from studying, parents, friends and other areas of social pressure. Encouraging children to participate in sports may assist them to release those pressures. 
In conclusion, the most important factor for children to participate in sport is from intrinsic motivation and also among those intrinsic reasons, "fun", physical fitness and familial factors play an important role. Furthermore, when children participate in sport, they may have more chance to meet friends, learn more about him/herself, and develop his/her lifetime sport. Therefore, it is important to further understand their motives in sports participation.

\section{Method}

\section{Participants}

Primary 4 to 6 students from three primary schools were participants in this research (males, $\mathrm{n}=89$; females, $\mathrm{n}=$ 216). The age range was 9 to 13 . They were divided into in age group 9 to $11(\mathrm{n}=216)$ and age group 12 to 13 $(n=89)$. The mean age of the subjects in this study was 10.8 years. The students were from two half-day primary schools and a whole-day primary school. Students who had even student number in each class were invited to take part in the present study.

\section{Instrument}

The questionnaire was mainly divided into two parts. The first part was personal information and questions related to sport participation patterns. For sport participation pattern, students were asked to write down which sports they were participating in extra-curricular activities. The survey also included items on basic information such as gender, age and primary class classification.

The second part was focused on the motivational factors of students participating in sport. The Chinese version of the Participation Motivation Questionnaire instrument (Fung et al., 1992; Gill, Gross \& Huddleston, 1983) was utilized in this study. This questionnaire is a popularly used standardized instrument for assessing motivation. The questionnaires consisted of 30 -items. The scale was developed to measure eight motivational factors, including achievement/status motives, team motives, fitness motives, energy release motives, skill motives, friends motives, fun motives and miscellaneous motives (See Appendix A). A three point Likert scale was used in the motivation part ranged from very important, somewhat important and not at all important. Students were asked to express their feeling on each item based on the scale.

\section{Results}

\section{Sport Participation Pattern}

There were $85.2 \%$ of subjects participating in sport during leisure, more than half of them (43\%) attended more than one type of sport $(\mathrm{N}=305)$. Primary school students usually participated in sports like badminton (8.5\%), basketball (7. $2 \%$ ), track and field (7.2\%), swimming (6.5\%), table-tennis (3.9\%), football $(3.3 \%)$, gymnastic $(0.7 \%)$ and volleyball $(0$. $3 \%$ ). The remaining $4.6 \%$ participated in other sports such as rope skipping, cycling, dance, ice-skating, roller blade, tennis, running, squash, baseball and judo. Badminton was the most popular sport for students. More than half of the primary school students $(71.8 \%)$ spent one to three hours per week to participate in sports, $9.2 \%$ of them spent four to six hours per week, $19 \%$ of them spent seven to more hours per week. However, result showed that the number of students participated in sport was decreasing with increasing age. The percentage from aged 9 to 13 primary school students participated in sport were $97.6 \%, 89.2 \%, 89.9 \%, 75.9 \%$ and $67.7 \%$ respectively.

\section{Participation Motives}

The 30 items participation motivation questionnaire could be grouped into eight factors. They were Achievement /Status, Team, Fitness, Energy release, Miscellaneous, Skills, Friends and Fun. In Table 1, the mean rank of score from highest to lowest were Fitness (2.25), Fun (2.24), Skill (2.24), Friends (2.23), Team (2.18), Energy release (1.80), Achievement/Status (1.76) and Miscellaneous (1.56) respectively. Fitness, Fun, Skill, Friends and Team were the top five participation motives for primary school students. 
Table 1. Participation Motives in Sport for 305 Students.

\begin{tabular}{llll}
\hline Rank & Factor & $M$ & $S D$ \\
\hline 1 & Fitness & 2.25 & .43 \\
2 & Skills & 2.24 & .49 \\
3 & Fun & 2.24 & .51 \\
4 & Friends & 2.23 & .46 \\
5 & Team & 2.18 & .51 \\
6 & Energy Release & 1.80 & .40 \\
7 & Achievement/Status & 1.76 & .49 \\
8 & Miscellaneous & 1.56 & .47 \\
\hline
\end{tabular}

Moreover, a 2 × 2 × 2 Analysis of Variance (ANOVA) was utilized to test the main effect and interaction effect among gender, school type and age group in each of the motivational factors. Findings indicated that there was significant mean difference in team factor for students who studied in wholeday school and half-day school $(\mathrm{F}=.4 .532, \mathrm{p}=.034)$, friends factor $(\mathrm{F}=5.548, \mathrm{p}=.019)$ and miscellaneous factor $(\mathrm{F}=4$. $816, \mathrm{p}=.029)$. This reflected that students who studied in whole-day primary schools had higher mean scores in these factors than half-day primary schools' students. Result also showed that there was significant mean difference for males and females students in miscellaneous factor $(\mathrm{F}=7.024, \mathrm{p}=$ .008). Male students rated a higher mean score in this factor than female students. Significant mean difference were found for younger age group students and older age group students on fun factor $(\mathrm{F}=5.42, \mathrm{p}=.021)$ and friends factor $(\mathrm{F}=5$. $759, \mathrm{p}=.017)$. Younger age group students had higher score in these factors than older age group students. No interaction effect was found on the motivational factors. Details were shown in Table 2.

Table 2. Main Effect of Males and Females of Age Group and School Type on the Participation Motives.

\begin{tabular}{|c|c|c|c|c|}
\hline Factors & Source & $M$ & $F$ & $p$ \\
\hline \multirow[t]{2}{*}{ Team } & Whole-day primary school & 6.91 & $4.532^{*}$ & .034 \\
\hline & Half-day primary school & 6.31 & & \\
\hline \multirow[t]{4}{*}{ Miscellaneous } & Whole-day primary school & 5.11 & $4.816^{*}$ & .029 \\
\hline & Half-day primary school & 4.41 & & \\
\hline & Males & 5.18 & $7.024 *$ & .008 \\
\hline & Females & 4.46 & & \\
\hline Fun & Younger age group & 6.81 & $5.42 *$ & .021 \\
\hline - & Older age group & 6.48 & & \\
\hline \multirow[t]{4}{*}{ Friends } & Whole-day & 9.31 & $5.548^{*}$ & .019 \\
\hline & Half-day & 8.7 & & \\
\hline & Younger age group & 9.04 & $5.759^{*}$ & .017 \\
\hline & Older age group & 8.64 & & \\
\hline
\end{tabular}

$* p<.05$ 
Furthermore, Independent t-test was utilized to examine the mean difference for sport participants and non-sport participants on motivational factors. The mean scores of the seven motivational factors in sport participants were higher than non-sport participants except for the miscellaneous factor. Analysis revealed that there was significant mean difference found in team factor $(t=2.143, p=.033)$, fitness factor $(t=2.747, p=.006)$, energy release factor $(t=2.341, p=.02)$, friends factor $(t=1.986$, $\mathrm{p}=.048)$ and fun factor $(\mathrm{t}=2.491, \mathrm{p}=.013)$. Sport participants had higher mean scores in these five factors than non-sport participants. Details as shown in Table 3.

Table 3. Independent T-test Comparing for Primary School Student with Different Sport Involvement $(\mathrm{N}=305)$.

\begin{tabular}{|c|c|c|c|c|c|}
\hline$\underline{\text { Factor }}$ & Sport Involvement Type & $M$ & $S D$ & $t$ & $p$ \\
\hline Achievement/ & Sport participants ${ }^{a}$ & 9.09 & 2.45 & .453 & .651 \\
\hline Status & Non-sport participants ${ }^{b}$ & 8.91 & 2.64 & & \\
\hline \multirow[t]{2}{*}{ Team } & Sport participants a & 6.61 & 1.48 & $2.143^{*}$ & .033 \\
\hline & Non-sport participants ${ }^{b}$ & 6.09 & 1.70 & & \\
\hline \multirow[t]{2}{*}{ Fitness } & Sport participants a & 6.83 & 1.26 & $2.747^{*}$ & .006 \\
\hline & Non-sport participants ${ }^{b}$ & 6.27 & 1.40 & & \\
\hline \multirow[t]{2}{*}{ Energy release } & Sport participants a & 9.13 & 1.98 & $2.341^{*}$ & .020 \\
\hline & Non-sport participants ${ }^{b}$ & 8.38 & 2.11 & & \\
\hline \multirow[t]{2}{*}{ Skill } & Sport participants ${ }^{a}$ & 6.77 & 1.44 & 1.256 & .210 \\
\hline & Non-sport participants ${ }^{b}$ & 6.47 & 1.63 & & \\
\hline \multirow[t]{2}{*}{ Friends } & Sport participants a & 9.01 & 1.83 & $1.986^{*}$ & .048 \\
\hline & Non-sport participants ${ }^{b}$ & 8.42 & 1.86 & & \\
\hline \multirow[t]{2}{*}{ Fun } & Sport participants a & 6.81 & 1.49 & $2.491^{*}$ & .013 \\
\hline & Non-sport participants ${ }^{b}$ & 6.20 & 1.60 & & \\
\hline \multirow[t]{2}{*}{ Miscellaneous } & Sport participants a & 4.63 & 1.37 & -1.017 & .31 \\
\hline & Non-sport participants ${ }^{b}$ & 4.87 & 1.65 & & \\
\hline
\end{tabular}

$* p<.05$

${ }^{a} \mathrm{n}=260 \quad{ }^{\mathrm{b}} \mathrm{n}=45$

\section{Discussions}

The aims of this study were to investigate the sport participation pattern and participation motives of primary school students.

The result showed that the majority of the primary school students $(85.2 \%)$ have participated in sport during leisure. 71 . $8 \%$ had engaged one to three hours per week in sports. However, the percentage of primary school students participated in sports was decreased with increasing age. This result was similar to studies like Knop, Enström and Skirstad (1996) and Weiss and Petlich (1989) stated that the number of dropout rate for student to participate in sports was increasing with increasing age. In this study, primary school students have participated in more than one kind of sports (43\%) rather than just focus on one individual/team sport. This information might be helpful for physical education teachers when planning sport programs and teaching strategies.

Moreover, the information revealed that the top five participation motives for primary school students were fitness, fun, skill, friends and team aspects. This result was consistent to results from previous researchers, such as Gill et al. (1983) showed that fun and skill were the most important reasons for age 8 to 18 youth to participate in sport. Similarly, Gould, 
Feltz and Weiss (1985) found that fun, fitness, skill improvement, team atmosphere and challenge as the most important motives for age from 8 to 19 years swimmers to participate in sport.

From the investigation, it was also found that there was significant gender difference in miscellaneous factors, meaning that male concerned more on this factor when participating in sports. In addition, in the miscellaneous factor, males ranked higher in items such as "like coach" and "can use the facilities". In addition, it is interesting to find that primary school students who studied in whole-day primary school have higher scores in some of the motivational factors than the half-day primary school students such as team, friends and miscellaneous when participating in sports. Findings also showed that students of the younger age group had higher scores in fun and friends factors than the older age group. It might be the case that children were concerned on these aspects when participating in sports (Taylor, et.al., 1998).

From this survey, students participated in sports during leisure time reported higher mean scores on achievement/status, team, fitness, energy release, skills, friends and fun factors. These seven intrinsic motivational factors placed an important part to motivate students for participating in sports. Significant differences were found on team, fitness, energy release, friends and fun factors between sport participants and non-sport participants.

\section{Conclusion}

Based on the data analysis, these are the following conclusions:

1. Primary students prefer to participate in variety of sports rather than one kind of Individual or Team sport.

2. The top five participation motives for Primary 4 to 6 students are Fitness, Skill, Fun, Friends and Team.

3. Higher mean score in Miscellaneous factor is found in male primary school students than in female primary school students.

4. The participation motives scores are different between whole-day school and half-day school on Team, Friends and Miscellaneous factors. Higher mean scores of these motivational factors are found in students who are studying in whole-day school than half-day school.
5. Younger age group students have higher mean scores on Fun and Friends factors than older age group students.

6. No interaction effect was found among gender, age group and school type on motivational factors.

7. Students participating in sports during leisure time have higher scores on motivational factors including team, fitness, energy release, friends and fun than those who does not participate in sports.

\section{Recommendations}

This study has shown that primary students prefer to participate in more than one kind of sport. Fitness, skill, fun, friends and team are the top five participation motives. Teachers and the activity organizers should introduce some interesting activities for students so that they can meet more friends. Moreover, activity involving some skill component may also motivate children to participate in an activity. Furthermore, appropriate fitness testing should be included to provide an indicator for children to understand their fitness level.

The following recommendations are suggested for further study:

1. Personal interview should be included to gather more information in participation motives.

2. The sample size of the research should be increased.

3. Participants from other age groups should be included.

4. Other than motivational factors and sport participation pattern, study which focus on the parental effects upon the schoolchildren's motivation in sport participation should be conducted. 


\section{Appendix A.}

The Participation Motives of Participation Motivation Questionnaire.

\begin{tabular}{|c|c|}
\hline Motives & Items \\
\hline Achievement/Status & $\begin{array}{l}\text { 3.- "like to win", } \\
\text { 10.- "like to do something I am good at" } \\
\text { 12.- "want to gain status and recognition" } \\
\text { 23.- "like the rewards" } \\
\text { 24.- "like to feel important" } \\
\text { 29.- "want to be popular" }\end{array}$ \\
\hline Team & $\begin{array}{l}\text { 8.- "like the team work" } \\
\text { 16.- "like the team spirit" } \\
\text { 21.- "like being on a team" }\end{array}$ \\
\hline Fitness & $\begin{array}{l}\text { 4.- "want to get rid of energy" } \\
\text { 14.- "want to release tension" } \\
\text { 18.- "like to travel" } \\
\text { 27.- "like to get out of the house" } \\
\text { 28.- "like to have something to do" }\end{array}$ \\
\hline Energy release & $\begin{array}{l}\text { 7.- "like to exercise" } \\
\text { 9.- "want to be physically fit" } \\
\text { 26.- "want to stay in shape" }\end{array}$ \\
\hline Skill & $\begin{array}{l}\text { 1.- "want to improve skill" } \\
\text { 15.- "like to go to a higher level" } \\
\text { 19.- "want to learn a new skill" }\end{array}$ \\
\hline Friends & $\begin{array}{l}\text { 2.- "want to be with my friends" } \\
\text { 6.- "like to meet new friends" } \\
\text { 13.- "like to compete" } \\
\text { 17.- "like the challenge" }\end{array}$ \\
\hline Fun & $\begin{array}{l}\text { 11.- "like the excitement" } \\
\text { 22.- "like to have fun" } \\
\text { 7.- "like the action" }\end{array}$ \\
\hline Miscellaneous & $\begin{array}{l}\text { 5.- "like the coach" } \\
\text { 20- "parents and friends want me to participate" } \\
\text { 25.- "like to use the equipment and facilities" }\end{array}$ \\
\hline
\end{tabular}

\section{References}

Biddle, S. (1992). Sport and exercise motivation: A brief review of antecedent factors and psychological outcomes of participation. Physical Education Review, 15(2), 98110 .

Coakley, J. (1993). Social dimensions of intensive training and participation in youth sports. In B. R. Cahill \& A. J. Pearl (Eds.), Intensive participation in children's sports (pp. 77-94). Human Kinetics Publishers.

Darley, A., \& O'Gara, A. (1998). Age, gender and motivation for participation in extra curricular physical activities in secondary school adolescents. European Physical Education Review 4(1), 47-53.
Eccles, J. S., \& Harold, R. D. (1991). Gender differences in sport involvement: Applying the Eccles' expectancyvalue model. Journal of Applied Sport Psychology, 3, 7-35.

Estrade, A. M., Gelfand, D. M., \& Hartmann, D. P. (1988). Children's sport and the development of social behaviors. In F. L. Smoll, R. A. Magill \& M. J. Ash (Eds.), Children in sport (pp. 251-259). Champaign, IL: Human Kinetics.

Fung, L., Ha, A., Louie, L., \& Poon, F. (1992). Sport participation motives among return track and field athletes. Journal of International Council for Health and Physical Education and Recreation, 26(1), 24-28. 
Gill, D. L. (1994). Psychological perspectives on women in sport and exercise. In D. M. Costa \& S. R. Guthrie (Eds.), Women and sport (pp. 253-278). Champaign, IL: Human Kinetics.

Gill, D. L., Gross, J. B., \& Huddleston, S. (1983). Participation motivation in youth sports. International Journal of Sport Psychology, 14, 1-14.

Gould, D., Feltz, D., \& Weiss, M. (1985). Motives for participation in competitive youth swimming. International Journal of Sport Psychology, 16, 126-140.

Grove, J. R., Hood, K., Blanksby, B. A., \& Bloomfield, J. (1994). Psychological development of participants in highlevel junior sport. In B. A. Blanksby, J. Bloomfield, T. R. Ackland, B. C. Elliot \& A. R. Morton (Eds.), Athletics, growth, and development in children (pp. 123137). The University of Western Australia Study: Harwood Academic.

Iso-Ahola, S. (1989). Motivation for leisure. In E. L. Jackson \& T. L. Burton (Eds.), Understanding leisure and recreation: Mapping the past charting the future (pp. 247-279). State College: R. A. Venture Publishing.

Jung, P. H. (1998). Sport participation and its relationship to children's emotion. A Sport Science Conference on "Attaining Health, Fitness and Wellness in the $21^{\text {st }}$ Century" 1998.

Kirkby, R. J., Kolt, G. S., \& Liu, J. (1999). Participation motives of young australian and chinese gymnasts. Perceptual and Motor Skills, 88, 363-373.

Knop, P. D., Engström, L. M., \& Skirstad, B. (1996). Worldwide trends in youth sport. In P. D. Knop, L. M. Engstrom, B. Skirstad, \& M. R. Weiss (Eds.), Worldwide trends in youth sport (pp. 276-281). Human Kinetics Publishers, Inc.
Ryckman, R. M. \& Harmel, J. (1993). Perceived physical ability differences in the sport participation motives of young athletes. International Journal of Sport Psychology, 24, 270-283.

Scanlan, T. K., \& Lewthwaite, R. (1986). Social psychological aspects of competition for male youth sport participants: IV. Predictors of enjoyment. Journal of Sport Psychology, 8, 25-35.

Shields, D. L., \& Bredemeier, B. J. (1995). Character development and physical activity. Champaign, IL: Human Kinetics.

Taylor, W. C., Blair, S. N., Cummings, S. S., Wun, C. C., \& Malina, R. M. (1998). Childhood and adolescent physical activity patterns and adult physical activity. Medicine \& Science in Sports \& Exercise, 30, 119-123.

Vogler, C. C., \& Schwartz, S. E. (1993). The sociology of sport. Englewood, NJ: Prentice-Hall.

Weiss, M. R., \& Petlichkoff, L. M. (1989). Children's motivation for participation in and withdrawal from sport: Identifying the missing links. Pediatric Exercise Science, 1, $195-$ 211.

\section{Correspondence:}

Author: Wong Po Chun, Ann

Institution: Department of Physical Education, Hong Kong Baptist University

Address: 16/F, Flat G, Block 10, Site 9, Whampoa Garden, Hung Hom, Kowloon, Hong Kong.

Tel: 852-9675-0427

Author: Dr. Siu-yin Cheung Institution: Department of Physical Education, Hong Kong Baptist University

Address: Room 114, Department of Physical Education, Hong Kong Baptist University, Hong Kong.

Tel: 852-3411-5637 